This item was submitted to Loughborough's Research Repository by the author.

Items in Figshare are protected by copyright, with all rights reserved, unless otherwise indicated.

\title{
Introduction to the special issue on climate change targets and urban transport policy
}

PLEASE CITE THE PUBLISHED VERSION

http://dx.doi.org/10.1016/j.retrec.2016.04.004

PUBLISHER

(C) Elsevier

VERSION

SMUR (Submitted Manuscript Under Review)

\section{PUBLISHER STATEMENT}

This work is made available according to the conditions of the Creative Commons Attribution-NonCommercialNoDerivatives 4.0 International (CC BY-NC-ND 4.0) licence. Full details of this licence are available at: https://creativecommons.org/licenses/by-nc-nd/4.0/

\section{LICENCE}

CC BY-NC-ND 4.0

\section{REPOSITORY RECORD}

Attard, Maria, Lucy Budd, and Robin Hickman. 2019. "Introduction to the Special Issue on Climate Change Targets and Urban Transport Policy”. figshare. https://hdl.handle.net/2134/21967. 


\section{Introduction to the Special Issue on Climate Change Targets and Urban Transport Policy}

Maria Attard, Lucy Budd and Robin Hickman

This special issue presents eight papers that were delivered at the International Conference on Climate Change Targets and Urban Transport Policy which was hosted by the Institute of Climate Change and Sustainable Development at the University of Malta, in conjunction with the WCTRS SIG G3 Urban Transport Planning and Policy, in Valletta on 13-14 ${ }^{\text {th }}$ April 2015. The conference brought together 68 academics, practitioners, policy makers, representatives of environmental NGOs and postgraduate students from 19 countries on 4 continents. Delegates travelled from Australia, India, Israel, Japan, Turkey, and the US, in addition to 13 European nations, to attend. The two-day conference included 3 key note presentations, 6 paper sessions and 2 poster sessions in which 23 papers and 13 posters were delivered, debated and discussed. This special issue brings together a selection of the papers that were presented at this event to showcase the latest research in the area of climate change and sustainable urban transport policy.

Reconciling rising levels of urbanization and increasing demand for urban mobility with environmental sustainability and the need to limit the global impact of climate change means the research need is urgent and compelling. In 2014, the UN estimated that $54 \%$ of the world's population lived in urban areas (up from $30 \%$ in 1950) and while considerable disparities in levels of urbanisation are evident, this figure is projected to increase to $66 \%$ by 2050 (UN, 2014). It is imperative, therefore, that research both seeks to understand the drivers of, and implications resulting from, increased demand for urban mobility and evaluate the extent to which different policy options and technological interventions can be used to meet the climate change mitigation targets that have been established.

Given the scale of the challenge, it was unsurprising that the research presented at the conference was theoretically and empirically diverse. Papers explored everything from local air pollution in Italian cities to the creation of integrated multi-modal urban transport systems in Asia and the efficacy of the various policy options, behavioural change incentives and technological interventions in addressing the social, economic and environmental challenges facing planners, policy makers and users of urban transport systems. As such, the conference collated international experiences of the performance of urban transport planning and policy in selected cities and city regions in developed, rapidly industrialising and less developed nations. Papers focused on the full range of urban transport modes, from active travel and public and private motorised modes, to light and heavy rail, the potential of urban cable transport and the future of commercial aviation. The empirical evidence that was presented resulted from detailed economic analyses of the effects of fuel prices on urban 
transport demand and mode choice, the environmental effects of airport congestion and inbound delays to aircraft, and cost benefit appraisals of different policy interventions and development projects. 